\title{
Successful Treatment of Scleredema Diabeticorum by Combining Local PUVA and Colchicine: A Case Report
}

\author{
Chayada Kokpol Natta Rajatanavin \\ Ploysyne Rattanakemakorn
}

Dermatology Unit, Department of Medicine, Faculty of Medicine, Ramathibodi

Hospital, Mahidol University, Bangkok, Thailand

\section{Key Words}

Scleredema $\cdot$ PUVA $\cdot$ Colchicine

\begin{abstract}
Scleredema is a rare condition of unknown pathogenesis. It is classically divided into three types, based on its association with postinfection (usually streptococcal), monoclonal gammopathy and diabetes mellitus (scleredema diabeticorum). Scleredema diabeticorum often has a subtle onset, persistent involvement and is refractory to therapies. Numerous therapies have been tried, with mixed and inconsistent results. We report herein a case of scleredema diabeticorum that was successfully treated by combining local PUVA with colchicine.
\end{abstract}

\section{Introduction}

Scleredema is a rare condition of unknown pathogenesis. It is characterized by symmetrical, non-pitting hardening and induration of the skin, most commonly seen on the upper back, shoulder and neck, due to excessive increase in mucin deposition between the thickened and broadened collagen bundles. Scleredema is classically divided into three types, based on its association with postinfection (usually streptococcal), monoclonal gammopathy and diabetes mellitus (scleredema diabeticorum).

Scleredema diabeticorum often has a subtle onset, persistent involvement and is refractory to therapies. Numerous therapies have been tried, with mixed and inconsistent results. No standard of treatment for this disease is currently known. 
Recently, UVA1 [1, 2], bath PUVA [3], cream PUVA [4], low-dose broad-band UVA combined with colchicine [5], narrow-band UVB [6], prostaglandin E1 [7] and tamoxifen [8] have been reported to improve the treatment of the disease in a scattering of studies. We report herein a case of scleredema diabeticorum that was successfully treated by combining local PUVA with colchicine.

\section{Case Presentation}

A 53-year-old Thai woman with a history of long-standing and poorly controlled diabetes mellitus presented to our outpatient dermatologic clinic because of a 2-year history of progressive thickening and wooden induration of her posterior neck and upper back (fig. 1). She could not lie in a supine position due to pain and paresthesia. At night, she had to sleep on her side or lie prone. Furthermore, to relieve her symptoms, she was using analgesic drugs daily. Her shoulder range of movement was also limited.

Incisional biopsy was done and the histopathological result was compatible with scleredema. In addition, her serum protein electrophoresis was normal. Epidermal thickness at the skin lesion measured with a $17-\mathrm{MHz}$ probe ultrasound was $0.7 \mathrm{~mm}$ (slight thickening), and dermal thickness was $6.4 \mathrm{~mm}$ (obvious thickening with diffuse hyperechogenicity) (fig. 2 ).

The patient received local PUVA treatment 2 times per week using oral 8-MOP and local UVA (Partial Body UV Therapy System UV 181; Waldmann Medical Technology) which irradiated only her upper back and posterior neck. Even after the tenth PUVA treatment alone, the patient still did not notice a significant skin improvement. Therefore, we added colchicine $1.8 \mathrm{mg} /$ day to our treatment.

Her lesion started to improve significantly after the twentieth PUVA+colchicine treatment. Fifty and $80 \%$ softening of the skin and pain reduction were noticed on a visual analogue scale after the twentieth and fortieth treatment, respectively.

At the end of the treatment (fiftieth treatment), the 17-MHz probe ultrasound was repeated at the same site. Epidermal thickness had decreased from 0.7 to $0.46 \mathrm{~mm}$ (34.28\% reduction of epidermal thickness) and dermal thickness from 6.4 to $5.95 \mathrm{~mm}$ (7.03\% reduction of dermal thickness) (fig. 3 ). Furthermore, the patient could lie in a supine position without taking analgesic drugs at night.

\section{Discussion}

Treating scleredema diabeticorum is quite difficult and of limited success. At present, no effective treatment is known for this disease. PUVA is now used in sclerotic disorders because of its multiple effects on collagen and dermal fibroblasts. In vitro, PUVA can reduce types I and III collagen synthesis and collagen mRNA levels in a UVA dose-dependent manner [9]. Furthermore, UVA can stimulate collagenase synthesis by human skin fibroblasts, which may enhance the degradation of sclerotic tissue [10-12]. Colchicine, instead, has an inhibitory effect on collagen by interfering with the transport and secretion of collagen $[13,14]$. Colchicine was also able to suppress the TGF- $\beta$-induced upregulation of type I collagen mRNA expression and the basal level of type I collagen mRNA in human dermal fibroblasts [15]. Therefore, combining these two methods might have a synergistic effect that can be used for the treatment of any sclerotic disorder. We herein reported the first case of a successful combination of local PUVA and colchicine in the treatment of scleredema diabeticorum. 


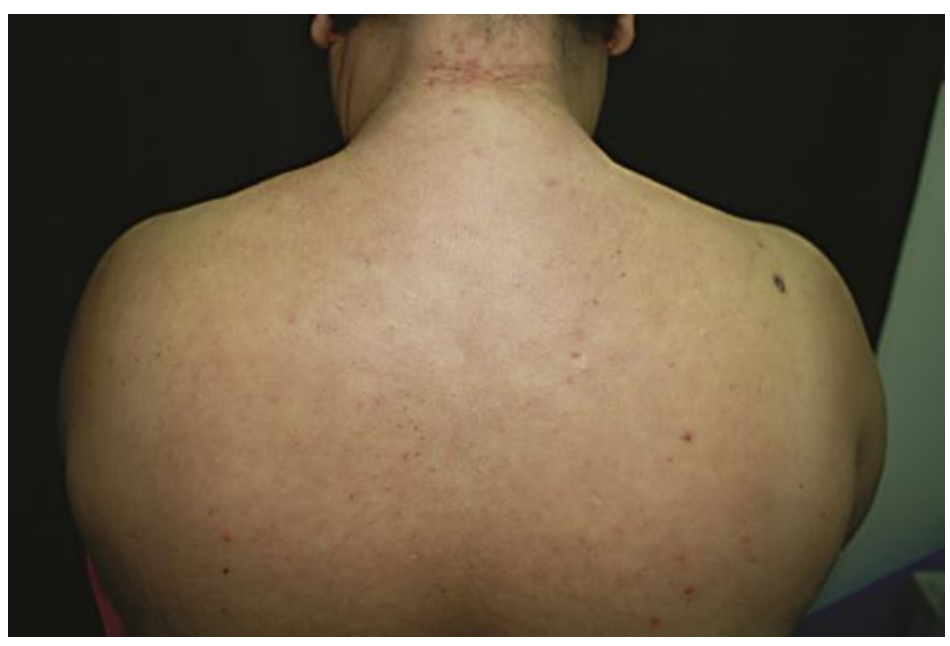

Fig. 1. Symmetrical, firm, non-pitting hardening and induration of the back at the first examination.

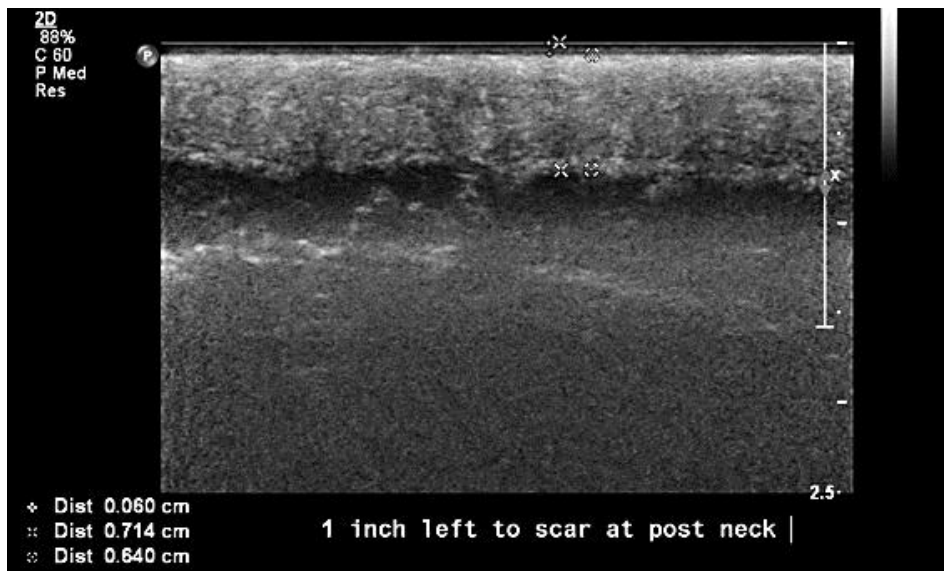

Fig. 2. Skin ultrasound before treatment showed a dermal thickness of $6.4 \mathrm{~mm}$. 


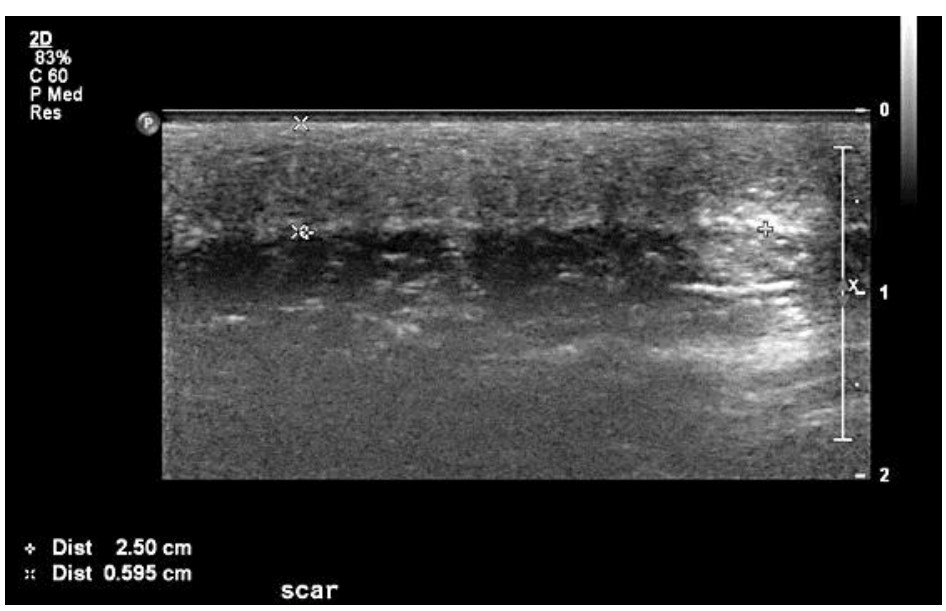

Fig. 3. Skin ultrasound after treatment showed a dermal thickness of $5.95 \mathrm{~mm}$.

\section{References}

1 Thumpimukvatana N, Wongpraparut C, Lim HW: Scleredema diabeticorum successfully treated with ultraviolet A1 phototherapy. J Dermatol 2010;37:1036-1039.

-2 Kroft EB, de Jong EM: Scleredema diabeticorum case series: successful treatment with UV-A1. Arch Dermatol 2008;144:947-948.

3 Hager CM, Sobhi HA, Hunzelmann N, et al: Bath-PUVA therapy in three patients with scleredema adultorum. J Am Acad Dermatol 1998;38:240-242.

-4 Grundmann-Kollmann M, Ochsendorf F, Zollner TM, Spieth K, Kaufmann R, Podda M: Cream PUVA therapy for scleredema adultorum. Br J Dermatol 2000;142:1058-1059.

-5 Yüksek J, Sezer E, Köseoğlu D, Markoç F, Yildiz H: Scleredema treated with broad-band ultraviolet A phototherapy plus colchicine. Photodermatol Photoimmunol Photomed 2010;26:257-260.

6 Xiao T, Yang ZH, He CD, Chen HD: Scleredema adultorum treated with narrow-band ultraviolet B phototherapy. J Dermatol 2007;34:270-272.

7 Ikeda Y, Suehiro T, Abe T, et al: Severe diabetic scleredema with extension to the extremities and effective treatment using prostaglandin E1. Intern Med 1998;37:861-864.

8 Alsaeedi SH, Lee P: Treatment of scleredema diabeticorum with tamoxifen. J Rheumatol 2010;37:26362637.

9 Kitamura Y, Namikawa H, Hayashi S, et al: Effects of UVA irradiation following treatment with 8methoxypsoralen on type I and type III collagen synthesis in normal and scleroderma fibroblast cultures. Arch Dermatol Res 2009;301:507-513.

10 Scharffetter K, Wlaschek M, Hogg A, et al: UVA irradiation induces collagenase in human dermal fibroblasts in vitro and in vivo. Arch Dermatol Res 1991;283:506-511.

-11 Petersen MJ, Hansen C, Craig S: Ultraviolet A irradiation stimulates collagenase production in cultured human fibroblasts. J Invest Dermatol 1992;99:440-444.

12 Brenner M, Herzinger T, Berking C, Plewig G, Degitz K: Phototherapy and photochemotherapy of sclerosing skin diseases. Photodermatol Photoimmunol Photomed 2005;21:157-165.

13 Dehm P, Prockop DJ: Time lag in the secretion of collagen by matrix-free tendon cells and inhibition of the secretory process by colchicine and vinblastine. Biochim Biophys Acta 1972;264:375-382.

14 Ehrlich HP, Ross R, Bornstein P: Effects of antimicrotubular agents on the secretion of collagen. A biochemical and morphological study. J Cell Biol 1974;62:390-405.

15 Chung KY, Kang DS: Regulation of type I collagen and interstitial collagenase mRNA expression in human dermal fibroblasts by colchicine and D-penicillamine. Yonsei Med J 1999;40:490-495. 